Jurnal Akuntansi dan Bisnis: Jurnal Program studi Akuntansi, 6 (1) Mei 2020.

ISSN 2443-3071 (Print) ISSN 2503-0337 (Online). DOI: 10.31289/jab.v6i1.2825

JURNAL AKUNTANSI DAN BISNIS

Jurnal Program Studi Akuntansi

Available online http://ojs.uma.ac.id/index.php/jurnalakundanbisnis

\title{
ANALISIS FINANCIAL DISTRESS PADA PERUSAHAAN PERTAMBANGAN BATU BARA YANG TERDAFTAR DI BURSA EFEK INDONESIA PERIODE 2017-2018
}

\author{
Reza Septian Pradana $a^{*}$ \\ ${ }^{a}$ Fungsional Statistisi Ahli BPS, Kabupaten Aceh Jaya \\ Diterima Agustus 2019, Disetujui November 2019, Dipublikasikan Mei 2020
}

\begin{abstract}
Abstrak
Penelitian ini bertujuan untuk mengidentifikasikondisi financial distress pada perusahaan pertambangan batu bara yang terdaftar di Bursa Efek Indonesia dan menganalisis faktor-faktor yang memengaruhinya. Penelitian ini menggunakan analisis metodologi regresi logistik. Hasil telaah laporan keuangan tahunan 23 perusahaan pertambangan batu bara yang terdaftar di Bursa Efek Indonesia periode 2017-2018 diperoleh informasi 5 perusahaan mengalami financial distress. Hasil estimasi dengan regresi logistic menunjukkan bahwa ukuran perusahaan dan Debt to Equity Ratio (DER) secara signifikan berpengaruh terhadap peluang perusahaan pertambangan batu bara mengalami financial distress. Dengan demikian, perusahaan pertambangan batu bara yang terdaftar di Bursa Efek Indonesia periode 2017-2018 perlu meningkatkan aset dan lebih mengandalkan pendanaan perusahaan dari ekuitas dibandingkan utang.
\end{abstract}

Kata Kunci: Debt to Equity Ratio (DER), Financial Distress, regresi logistik, ukuran perusahaan

\begin{abstract}
This study aims to identify financial distress for coal mining firms registered in Indonesia Stock Exchange and analyze the factors that influent. This study uses methodological logistic regression analysis. The result of analyzing annual financial report 23 coal mining firms registered in Indonesia Stock Exchange period 2017-2018 is that 5 firms get financial distress. The result of estimation using logistic regressionshows that firm size and Debt to Equity Ratio (DER) significantly influent to the opportunity of coal mining firms gets financial distress. Thus, coal mining firms registered in Indonesia Stock Exchange period 2017-2018 need to enhance asset and use equity more than debt for firm's funding.
\end{abstract}

Keyword: Debt to Equity Ratio (DER), Financial Distress, logistic regression, firm size

How To Cite: Reza Septian Pradana (2020) Analisis Financial Distress Pada Perusahaan Pertambangan Batu Bara Yang Terdaftar Di Bursa Efek Indonesia Periode 2017-2018. Jurnal Akuntansi dan Bisnis: Jurnal Program Studi Akuntansi, 6 (1): 36-45

* email: reza.sp@bps.go.id

\section{PENDAHULUAN}

Pada hakekatnya, tujuan utama pendirian suatu perusahaan bagi pengusaha adalah untuk memperoleh keuntungan yang maksimal (Ardimas, W., dan Wardoyo, W. 2015). Dengan perolehan keuntungan inilah perusahaan akan mampu bertahan dan berkembang. Kondisi perekonomian yang tidak menentu seringkali mempengaruhi kinerja keuangan perusahaan. Jika manajemen tidak mampu mengelola dengan baik maka bayangan penurunan kinerja keuangan bahkan bahaya kebangkrutan perusahaan akan dihadapi perusahaan (Liana dan Sutrisno, 2014).

Sebuah perusahaan tentu akan menghindari berbagai kondisi yang akan mengakibatkan kebangkrutan. Putri dan Merkusiwati (2014) menegaskan bahwa 
kebangkrutan merupakan kondisi financial distress yang terburuk. Kebangkrutan perusahaan akan mengakibatkan berbagai kerugian baik bagi pemegang saham, karyawan dan perekonomian nasional (Al-Khatib dan Al-Horani, 2012). Menurut Murni (2018), financial distress adalah kondisi dimana keuangan perusahaan dalam keadaan tidak sehat atau krisis. Almila (2006) mengatakan bahwa financial distress merupakan suatu kondisi yang menunjukkan tahap penurunan dalam kondisi keuangan perusahaan yang terjadi sebelum terjadinya kebangkrutan atau likuidasi. Financial distress dapat juga didefinisikan sebagai ketidakmampuan perusahaan untuk membayar kewajibankewajiban financial yang telah jatuh tempo (Dwijayanti, 2010).

Menurut Almilia (2004), laporan keungan merupakan salah satu sumber mengenai posisi keuangan yang dialami oleh perusahaan, kinerja serta perubahan pada posisi keuangan yang sangat berguna untuk mendukung pengambilan keputusan yang tepat. Dengan laporan keuangan ini, berbagai pihak mengetahui lebih dini mengenai financial distress yang dialami oleh perusahaan. Almilia (2004) mengemukakan bahwa financial distress terjadi apabila perusahaan mengalami laba bersih operasi (net operating income) negatif beberapa tahun. Hal ini dipertegas kembali oleh Ginting, D. Y. (2018) bahwa perusahaan mengalami financial distress apabila memiliki laba bersih negatif sekurang-kurangnya dua tahun berturut-turut. Perusahaan yang mengalami laba operasi selama lebih dari setahun menunjukkan telah terjadi tahap penurunan kondisi keuangan suatu perusahaan. Jika tidak ada tindakan perbaikan yang dilakukan manajemen perusahaan maka perusahaan dapat mengalami kebangkrutan (Ainun, M. B. 2019).

Menurut Afriyeni (2012), apabila ditinjau dari kondisi keuangan ada tiga keadaan yang menyebabkan financial distress yaitu faktor ketidakcukupan modal atau kekurangan modal, besarnya beban utang dan bunga serta menderita kerugian. Pada umumnya, kemungkinan mengalami financial distress semakin besar seiring dengan peningkatan penggunaan utang. Secara logika, jika semakin besar penggunaan utang maka semakin besar pula beban biaya bunga sehingga profitabilitas akan menurun dan mengakibatkan financial distress (Indrasari, A., Yuliandhari, W. S., \& Triyanto, D. N. 2016). Menurut Harahap (2011), Debt to Equity (DER) adalah rasio utang terhadap ekuitas yaitu mencerminkan kemampuan perusahaan dalam memenuhi seluruh kewajibannya yang ditunjukkan oleh berapa bagian dari modal sendiri yang digunakan untuk membayar utang. Hasil penelitian yang dilakukan oleh Hendra et, al (2017) menunjukkan bahwa leverage yang diukur dengan DER secara sugnifikan berpengaruh terhadap financial distress.

Selain utang, ukuran perusahaan juga memengaruhi kemungkinan suatu perusahaan mengalami financial distress. Ukuran perusahaan adalah besar kecilnya perusahaan dilihat dari besarnya nilai equity, nilai penjualan atau nilai aktiva (Riyanto, 2008). Ghozali (2006) mengatakan bahwa ukuran perusahaan dapat dihitung dengan logaritma natural dari total aset (Ln Total Aset). Semakin besar aset yang dimiliki oleh suatu perusahaan maka perusahaan dapat melakukan investasi baik untuk aset lancar maupun aset tetap. Hasil penelitian yang dilakukan oleh Amarila et, al (2017) menunjukkan bahwa ukuran perusahaan secara signifikan berpengaruh terhadap financial distress.

Dari sekian banyaknya perusahaan yang terdaftar di Bursa Efek Indonesia, perusahaan pertambangan batu bara cukup menjadi sorotan dalam dunia bisnis saat ini. Hal ini dikarenakan kinerja perusahaan batu bara mengalami penurunan sehingga rentan mengalami financial distress. Penurunan kinerja perusahaan batu bara berkaitan dengan turunnya harga batu bara, lemahnya ekonomi China, over produksi gas serpih 
domestik, dan tantangan regulator (Kompas, 14 April 2016). Cina sebagai konsumen energi terbesar dunia sedang berupaya mengurangi intensitas penggunaan energi. Keputusan Cina mengurangi energi berdampak pada pengurangan penggunaan batu bara (Nasution, 2016). Cina membatasi impor batu bara termasuk dari Indonesia padahal Cina merupakan mitra dagang yang paling penting bagi Indonesia. Di sisi lain pengungkapan tanggung jawab sosial perusahaan pada perusahaan pertambangan juga dibutuhkan demi sustainability. Oktariani, N. W., \& Mimba, N. P. S. H. (2014).

Penelitian ini bertujuan untuk mengindentifikasi kondisi financial distress pada perusahaan pertambangan batu bara yang terdaftar di Bursa Efek Indonesia Periode 2017-2018 dan menganalisis faktor-faktor yang memengaruhinya, Hal ini bermanfaat bagi perusahaan untuk memperoleh informasi terkait upaya yang dapat dilakukan agar tidak mengalami financial distress. Adapun hipotesis yang digunakan dalam penelitian ini adalah ukuran perusahaan dan Debt to Equity Ratio (DER) berpengaruh terhadap peluang perusahaan pertambangan batu bara yang terdaftar di Bursa Efek Indonesia mengalami financial distress.

\section{METODE PENELITIAN}

Penelitian dilakukan pada perusahaan pertambangan batu bara yang terdaftar di Bursa Efek Indonesia. Penarikan sampel perusahaan pada penelitian ini dilakukan secara purposive sampling. Sampel dalam penelitian ini adalah perusahaan pertambangan batu bara yang terdaftar di Bursa Efek Indonesia periode 2017-2018. Dengan demikian, sampel perusahaan pertambangan batu bara dalam penelitian ini berjumlah 23 perusahaan. Data yang digunakan dalam penelitian ini adalah data sekunder berupa data laporan keuangan perusahaan dan publikasi "IDX Annual Statistics" tahun 20172018. Data bersumber dari Bursa Efek Indonesia. Variabel dependen dalam penelitian ini yaitu financial distress. Kemudian, variabel bebas dalam penelitian ini yaitu ukuran perusahaan dan Debt to Equty Ratio(DER).

Identifikasi financial distress dilakukan melalui penelaahan terhadap laporan keuangan tahunan perusahaan. Pengkategorian suatu perusahaan mengalami financial distress dalam penelitian ini sesuai dengan kategori dari Almilia (2004) dan Anggraini (2013) dimana perusahaan akan mengalami financial distress apabila memiliki laba bersih negatif sekurang-kurangnya 2 periode laporan berturut-turut. Dengan demikian, perusahaan pertambangan batu bara yang memiliki laba bersih negatif pada periode 2017-2018 dikategorikan mengalami financial distress.

Metode analisis yang digunakan dalam penelitian ini adalah analisis regresi logistik. Latan (2014) mengatakan bahwa analisis regresi logistik digunakan untuk melihat pengaruh sejumlah variabel independen terhadap variabel dependen yang berupa variabel kategorik. Model yang akan digunakan dalam penelitian ini adalah sebagai berikut:

$$
F D_{i}=\frac{1}{1+e^{-\left(\beta_{0}+\beta_{1} \text { size }_{i}+\beta_{2} D E R_{i}\right)}}
$$

Persamaan diatas dapat juga ditulis sebagai berikut:

$$
\ln \left[\frac{F D_{i}}{1-F D_{i}}\right]=\beta_{0}+\beta_{1} \text { size }_{i}+\beta_{2} D E R_{i}
$$


Dimana:

$F D_{i} \quad$ : Financial Distress perusahaan i dimana bernilai 1 apabila mengalami financial distress dan bernilai 0 apabila tidak mengalami financial distress

$\beta_{0} \quad$ : Intersep

$\beta_{1}, \beta_{2}$ : Koefisien Regresi Variabel Independen

size $_{i}$ : Ukuran Perusahaan i yang diukur dengan nilai logaritma natural dari nilai total aset perusahaan

$D E R_{i} \quad$ : Debt to Equity RatioPerusahaan i

I : ADRO, ARII, ..., TOBA (Perusahaan Pertambangan yang terdaftar di Bursa Efek Indonesia Periode 2017-2018)

Regresi logistik tidak mensyaratkan asumsi linier terhadap hubungan antara variabel independen dan independen variabel sehingga dapat meng-handle efek non linier/ interaksi. Ada beberapa asumsi yang tidak perlu dipenuhi di dalam analisis regresi logistik. Pertama, variabel tidak diasumsikan harus berdistribusi normal. Kedua, variabel dependen tidak membutuhkan homoskedastisitas untuk setiap level dari variabel independen. Ketiga, error tidak diasumsikan berdistribusi normal. Keempat, regresi logistik tidak mensyaratkan variabel independen harus interval. (Latan, 2014). Namun demikian, beberapa asumsi regresi logistik harus tetap dipenuhi dan diaplikasikan untuk menjamin model yang dihasilkan memberikan hasil estimasi terbaik. Dalam penelitian ini, pengujian nonmultikolinearitas pada seluruh variabel independen tetap dilakukan.

\section{HASIL DAN PEMBAHASAN}

Kondisi Keuangan Perusahaan Pertambangan Batu Bara yang Terdaftar di Bursa Efek Indonesia Periode 2017-2018

Dari Tabel 1, diperoleh informasi bahwa 5 dari 23 perusahaan pertambangan batu bara yang terdaftar di Bursa Efek Indonesia periode 2017-2018 mengalami financial distress. Kelima perusahaan tersebut memiliki nilai laba bersih negatif selama dua tahun berturut-turut, yakni Atlas Resources Tbk. [S], Bara Jaya Internasional Tbk., Borneo Lumbung Energi \& Metal Tbk., Alfa Energi Investama Tbk. [S], dan SMR Utama Tbk. [S].

Tujuh perusahaan, yakni Adaro Energy Tbk. [S], Bumi Resources Tbk., Bayan Resources Tbk., Dian Swastatika Sentosa Tbk. [S], Golden Energy Mines Tbk. [S], Indo Tambangraya Megah Tbk. [S], dan Bukit Asam Tbk. [S] memiliki laba bersih diatas ratarata. Adaro Energy Tbk. [S] memiliki laba bersih tertinggi apabila dibandingkan dengan 22 perusahaan pertambangan batu bara lainnya periode 2017-2018. Sebaliknya, kerugian tertinggi dialami oleh Borneo Lumbung Energi \& Metal Tbk. Periode 20172018.

Pada dasarnya, jika semakin besar ukuran suatu perusahaan yang ditandai dengan besarnya aset perusahaan maka semakin banyak kegiatan operasional yang dilakukan oleh perusahaan. Kemudian, ini akan menambah pendapatan suatu perusahaan. Pada tahun 2018, ukuran sebagian besar perusahaan pertambangan batu bara yang terdaftar di Bursa Efek Indonesia periode 2017-2018 diatas rata-rata. Adaro Energy Tbk. [S] memiliki ukuran perusahaan terbesar apabila apabila dibandingkan dengan 22 perusahaan pertambangan batu bara lainnya periode 2017-2018. Sebaliknya, Alfa Energi Investama Tbk. [S] memiliki ukuran perusahaan terendah. Dapat dilihat pada Tabel 1. 
Reza Septian Pradana (2020) Analisis Financial Distress Pada Perusahaan Pertambangan Batu Bara Yang Terdaftar Di Bursa Efek...

Tabel 1. Identifikasi Kondisi Financial Distress pada 23 Perusahaan Pertambangan Batu Bara yang Terdaftar di Bursa Efek Indonesia Periode 2017-2018

\begin{tabular}{|c|c|c|c|c|c|c|}
\hline No & Kode & Nama Perusahaan & $\begin{array}{l}\text { Laba } \\
\text { Bersih } \\
2017\end{array}$ & $\begin{array}{l}\text { Laba } \\
\text { Bersih } \\
2018\end{array}$ & Ketegori & Kondisi* ${ }^{*}$ \\
\hline (1) & $(2)$ & (3) & (4) & (5) & (6) & (7) \\
\hline 1 & ADRO & Adaro Energy Tbk. [S] & 5582 & 5252 & 0 & NFD \\
\hline 2 & ARII & Atlas Resources Tbk. [S] & -61 & -96 & 1 & $F D$ \\
\hline 3 & ATPK & Bara Jaya Internasional Tbk. & -115 & -83 & 1 & $F D$ \\
\hline 4 & BORN & Borneo Lumbung Energi \& Metal Tbk. & -2078 & -120 & 1 & $F D$ \\
\hline 5 & BSSR & Baramulti Suksessarana Tbk. [S] & 860 & 899 & 0 & NFD \\
\hline 6 & BUMI & Bumi Resources Tbk. & 3272 & 2285 & 0 & NFD \\
\hline 7 & BYAN & Bayan Resources Tbk. & 3075 & 6097 & 0 & $N F D$ \\
\hline 8 & DEWA & Darma Henwa Tbk. [S] & 4 & 12 & 0 & $N F D$ \\
\hline 9 & DOID & Delta Dunia Makmur Tbk. & 424 & 740 & 0 & NFD \\
\hline 10 & DSSA & Dian Swastatika Sentosa Tbk. [S] & 1339 & 2016 & 0 & NFD \\
\hline 11 & FIRE & Alfa Energi Investama Tbk. [S] & -4 & -5 & 1 & $F D$ \\
\hline 12 & GEMS & Golden Energy Mines Tbk. [S] & 1051 & 1466 & 0 & $N F D$ \\
\hline 13 & GTBO & Garda Tujuh Buana Tbk. [S] & -26 & 83 & 0 & NFD \\
\hline 14 & HRUM & Harum Energy Tbk. [S] & 540 & 440 & 0 & NFD \\
\hline 15 & ITMG & Indo Tambangraya Megah Tbk. [S] & 2323 & 2944 & 0 & NFD \\
\hline 16 & KKGI & Resource Alam Indonesia Tbk. [S] & 110 & 31 & 0 & $N F D$ \\
\hline 17 & MBAP & Mitrabara Adiperdana Tbk. [S] & 740 & 668 & 0 & $N F D$ \\
\hline 18 & MYOH & Samindo Resources Tbk. [S] & 117 & 321 & 0 & $N F D$ \\
\hline 19 & PTBA & Bukit Asam Tbk. [S] & 2664 & 3994 & 0 & NFD \\
\hline 20 & PTRO & Petrosea Tbk. [S] & 68 & 268 & 0 & NFD \\
\hline 21 & SMMT & Golden Eagle Energy Tbk. [S] & 11 & 48 & 0 & NFD \\
\hline 22 & SMRU & SMR Utama Tbk. [S] & -22 & -72 & 1 & $F D$ \\
\hline 23 & TOBA & Toba Bara Sejahtera Tbk. [S] & 391 & 686 & 0 & NFD \\
\hline \multicolumn{2}{|c|}{ Rata-rata } & & 881 & 1212 & & \\
\hline
\end{tabular}

*NFD : Non Financial Distress $\quad$ FD : Financial Distress

Debt to Equity Ratio (DER) menunjukkan besarnya utang perusahaan yang dibandingkan dengan modal perusahaan. Semakin besar rasio ini maka risiko kebangkrutan perusahaan semakin besar sehingga investor enggan untuk berinvestasi atau menarik investasinya dari perusahaan yang bersangkutan. Pada tahun 2018, sebagian besar perusahaan pertambangan batu bara yang terdaftar di Bursa Efek Indonesia periode 2017-2018 memiliki nilai DER dibawah rata-rata dan lebih kecil dari satu. Nilai $D E R$ yang lebih kecil dari satu berarti perusahaan tersebut mengandalkan pendanaan dari ekuitas daripada penggunaan utang. Pada tahun 2018, Atlas Resources Tbk. [S] paling tidak solvable karena memiliki nilai $D E R$ tertinggi. Sebaliknya, Garda Tujuh Buana Tbk. [S] paling solvable karena memiliki nilai DER terendah. 
Tabel 2. Ukuran Perusahaan dan Debt to Equity Ratio (DER) pada 23 Perusahaan Pertambangan Batu Bara yang Terdaftar di Bursa Efek Indonesia. Tahun 2018

\begin{tabular}{|c|c|c|c|c|}
\hline No & Kode & Nama Perusahaan & $\begin{array}{l}\text { Ukuran } \\
\text { Perusahaan } \\
\text { (Size) }\end{array}$ & $D E R$ \\
\hline (1) & $(2)$ & (3) & (4) & (5) \\
\hline 1 & ADRO & Adaro Energy Tbk. [S] & 11,58 & 0,66 \\
\hline 2 & ARII & Atlas Resources Tbk. [S] & 8,54 & 9,31 \\
\hline 3 & ATPK & Bara Jaya Internasional Tbk. & 6,86 & 2,10 \\
\hline 4 & BORN & Borneo Lumbung Energi \& Metal Tbk. & 9,58 & 2,33 \\
\hline 5 & BSSR & Baramulti Suksessarana Tbk. [S] & 8,23 & 0,78 \\
\hline 6 & BUMI & Bumi Resources Tbk. & 10,95 & 6,67 \\
\hline 7 & BYAN & Bayan Resources Tbk. & 9,71 & 0,46 \\
\hline 8 & DEWA & Darma Henwa Tbk. [S] & 8,65 & 0,67 \\
\hline 9 & DOID & Delta Dunia Makmur Tbk. & 9,74 & 3,99 \\
\hline 10 & DSSA & Dian Swastatika Sentosa Tbk. [S] & 10,82 & 1,19 \\
\hline 11 & FIRE & Alfa Energi Investama Tbk. [S] & 6,29 & 1,45 \\
\hline 12 & GEMS & Golden Energy Mines Tbk. [S] & 9,28 & 1,19 \\
\hline 13 & GTBO & Garda Tujuh Buana Tbk. [S] & 6,81 & 0,15 \\
\hline 14 & HRUM & Harum Energy Tbk. [S] & 8,84 & 0,23 \\
\hline 15 & ITMG & Indo Tambangraya Megah Tbk. [S] & 10,00 & 0,47 \\
\hline 16 & KKGI & Resource Alam Indonesia Tbk. [S] & 7,40 & 0,25 \\
\hline 17 & MBAP & Mitrabara Adiperdana Tbk. [S] & 7,86 & 0,26 \\
\hline 18 & MYOH & Samindo Resources Tbk. [S] & 7,66 & 0,39 \\
\hline 19 & PTBA & Bukit Asam Tbk. [S] & 10,02 & 0,51 \\
\hline 20 & PTRO & Petrosea Tbk. [S] & 8,95 & 1,78 \\
\hline 21 & SMMT & Golden Eagle Energy Tbk. [S] & 6,70 & 0,75 \\
\hline 22 & SMRU & SMR Utama Tbk. [S] & 7,54 & 1,25 \\
\hline 23 & TOBA & Toba Bara Sejahtera Tbk. $[\mathrm{S}]$ & 8,67 & 0,92 \\
\hline \multicolumn{3}{|c|}{ Rata-rata } & 8,73 & 1,44 \\
\hline
\end{tabular}

\section{Pembentukkan Model Terbaik dan Pengujian Asumsi Dasar}

Sebelum dilakukan pembentukkan model terbaik, perlu dilakukan pengujian non multikolinearitas pada seluruh variabel independen dalam penelitian ini diperoleh hasil sebagai berikut:

Tabel 3. Uji Non Multikolinearitas

\begin{tabular}{ccc}
\hline & Tolerance & VIF \\
\hline DER & 0,960 & 1,041 \\
size & 0,960 & 1,041 \\
\hline
\end{tabular}

Asumsi Non-Multikolinearitas atas seluruh variabel bebas yang digunakan dalam model sudah terpenuhi. Hal ini dibuktikan dengan nilai Variance Inflation Factor (VIF) untuk seluruh variabel jauh lebih kecil dari 10 sehingga dapat disimpulkan tidak terjadi hubungan antara variabel bebas yang masuk ke dalam model. 
Reza Septian Pradana (2020) Analisis Financial Distress Pada Perusahaan Pertambangan Batu Bara Yang Terdaftar Di Bursa Efek...

Tabel 4. Uji Variance Inflation Factor (VIF)

Variables in the Equation

\begin{tabular}{|c|c|c|c|c|c|c|c|}
\hline & & $\mathrm{B}$ & S.E. & Wald & Df & Sig. & $\operatorname{Exp}(B)$ \\
\hline Step 0 & Constant & $-1,281$ & ,506 & 6,420 & 1 & 011 & 278 \\
\hline \multicolumn{8}{|c|}{ Variables not in the Equation } \\
\hline & & & Score & Df & & Sig. & \\
\hline \multirow[t]{3}{*}{ Step 0} & Variables & DER & 3,669 & 1 & & 055 & \\
\hline & & size & 2,945 & 1 & & 086 & \\
\hline & Overall $\mathrm{s}$ & istics & 8,252 & 2 & & 016 & \\
\hline
\end{tabular}

Output di atas merupakan Blok 0 atau blok permulaan adalah proses inisialisasi artinya variabel size dan DER belum dimasukkan ke dalam model penelitian. Dengan kata lain, model ini adalah model persamaan logistik yang hanya menggunakan konstanta saja untuk memprediksi perusahaan masuk ke dalam kategori Financial Distress atau tidak.

Nilai signifikansi konstanta sebesar 0,011 (lebih kecildari 0,10). Hal ini berarti bahwa dengan menggunakan model persamaan sederhana (hanya konstanta saja) sebenarnya sudah mampu memberikan penjelasan proporsi Financial Distress. Namun, jika digunakan model ini maka tujuan penelitian ini tidak tercapai yakni untuk menganalisis faktor-faktor yang memengaruhi financial distress. Dengan demikian, pembentukkan model dengan memasukkan variabel independen tetap harus dilakukan.

Tabel 5. penaksiran parameter (-2 Log likelihood)

\begin{tabular}{cccc}
\multicolumn{4}{c}{ Model Summary } \\
\hline Step & -2 Log likelihood & $\begin{array}{c}\text { Cox \& Snell R } \\
\text { Square }\end{array}$ & $\begin{array}{c}\text { Nagelkerke R } \\
\text { Square }\end{array}$ \\
\hline 1 & 14,165 a &, 350 &, 540 \\
\hline \multicolumn{3}{c}{ a. Estimation terminated at iteration number 7 because parameter } \\
estimates changed by less than , 001.
\end{tabular}

Dari Tabel 5. di atas, dapat dilihat bahwa model dengan memasukkan dua variabel independen ternyata telah terjadi perubahan dalam penaksiran parameter $(-2$ Log likelihood) sebesar 14,165. Jika dilihat nilai R-square sebesar 0,350(Cox \& Snell) dan 0,540 (Nagekerke). Dengan demikian, dapat ditafsirkan bahwa dengan dua variabel, yaitu size dan DER maka proporsi Financial Distress yang dapat dijelaskan sebesar 54\%. Tetapi,interpretasi ini hanya nilai pendekatan saja seperti dalam koefisien determinasi (regresi linier biasa).Dengan demikian model yang terbentuk adalah sebagai berikut:

Tabel 6. uji chi-square

Variables in the Equation

\begin{tabular}{cccccccc}
\hline & & B & S.E. & Wald & df & Sig. & Exp(B) \\
\hline \multirow{2}{*}{ Step 1a } & DER &, 950 &, 544 & 3,044 & 1 &, 081 & 2,585 \\
& size & $-1,463$ &, 747 & 3,839 & 1 &, 050 &, 231 \\
& Constant & 9,046 & 5,287 & 2,927 & 1 &, 087 & 8484,035 \\
\hline
\end{tabular}

a. Variable(s) entered on step 1: DER, size.

Model yang terbentuk diatas perlu dilakukan uji chi-square dari Hosmer and Lemeshow test. diperoleh hasil sebagai berikut pada Tabel 7:

Tabel 7. Hosmer and Lemeshow Test

\begin{tabular}{cccc}
\hline Step & Chi-square & Df & Sig. \\
\hline
\end{tabular}




\section{$\begin{array}{lrrr}1 & 8,414 & 8 & , 394\end{array}$}

Hasil uji chi-square yang dihasilkan memiliki nilai p-signifikansi sebesar 0,394 (lebih besar dari 0,10) maka terima H0. Kesimulanya, model yang terbentuk dapat digunakan untuk mengestimasi pengaruh ukuran perusahaan (size) dan Debt to Equity Ratio (DER) terhadap Financial Distress pada perusahaan pertambangan batu bara yang terdaftar di Bursa Efek Indonesia.

Faktor-Faktor yang Memengaruhi Financial Distress pada Perusahaan Pertambangan Batu Bara yang Terdaftar di Bursa Efek Indonesia Periode 2017-2018

Faktor-faktor yang memengaruhi Financial Distress pada Perusahaan Pertambangan Batu Bara yang Terdaftar di Bursa Efek Indonesia Periode 2017-2018 dapat dijelaskan melalui model berikut:

$$
\ln \left[\frac{F D_{i}}{1-F D_{i}}\right]=9,046-1,463^{*} \text { size }_{i}+0,950^{*} D E R_{i}
$$

Keterangan:

* signifikan pada alpha $10 \%$

Berdasarkan model diatas, peluang perusahaan pertambangan batu bara yang terdaftar di Bursa Efek Indonesia periode 2016-2017 akan mengalami Financial Distress secara signifikan dipengaruhi oleh ukuran perusahaan (size) dan Debt to Equity Ratio $(D E R)$. Hal ini dibuktikan dengan koefisien regresi logistik ukuran perusahaan (size) dan Debt to Equity Ratio (DER) signifikan (nilai prob t-stat kurang dari 0,1). Namun demikian model regresi logistik diatas tidak bisa langsung diinterpretasikan dari koefisien regresinya seperti regresi linier. Interpretasi dilakukan dengan melihat nilai dari $\exp \left(\beta_{i}\right)$ atau nilai eksponen dari koefisien persamaan regresi yang terbentuk.

Arah hubungan ukuran perusahaan (size) negatif dengan peluang suatu perusahaan mengalami financial distress. Hal ini berarti jika semakin besar ukuran perusahaan pertambangan batu bara maka semakin kecil peluang perusahaan tersebut mengalami financial distress. Nilai $\exp \left(\beta_{1}\right)$ dari ukuran perusahaan (size) sebesar 0,231 yang artinya bahwa dengan tingkat kepercayaan 90 persen peningkatan ukuran perusahaan (size) sebesar 1 satuanakan mengurangi peluangperusahaan pertambangan batu bara yang terdaftar di Bursa Efek Indonesia periode 2016-2017 mengalami financial distress sebesar 0,231 kali. Pada hakikatnya, jika semakin besar aset suatu perusahaan maka semakin besar juga aktivitas ekonomi dan penerimaan dari perusahaan tersebut. Hal ini akan mendukung kinerja keuangan perusahaan lebih baik sehingga memperkecil kemungkinan suatu perusahaan mengalami financial distress. Adanya pengaruh ukuran perusahaan (size) yang signifikan terhadap Financial Distress serupa dengan hasil penelitian yang dilakukan oleh Amarila, et, al. (2017).

Kemudian, arah hubungan Debt to Equity Ratio (DER) positif dengan peluang suatu perusahaan mengalami financial distress. Hal ini berarti jika semakin besar Debt to Equity Ratio (DER) maka semakin besar juga peluang perusahaan tersebut mengalami financial distress. Nilai $\exp \left(\beta_{2}\right)$ dari Debt to Equity Ratio $(D E R)$ sebesar 2,585 yang artinya bahwa dengan tingkat kepercayaan 90 persen peningkatan Debt to Equity Ratio (DER) sebesar 1 satuanakan meningkatkanpeluangperusahaan pertambangan batu bara yang terdaftar di Bursa Efek Indonesia periode 2016-2017 mengalami financial distresssebesar 2,585 kali. Riyanto (2008) mengatakan bahwa permodalan yang baik didasari oleh modal sendiri karena tahan resiko. Dengan bertambahnya modal pinjaman, 
Reza Septian Pradana (2020) Analisis Financial Distress Pada Perusahaan Pertambangan Batu Bara Yang Terdaftar Di Bursa Efek...

beban perusahaan akan bertambah karena perusahaan harus membayar bunga pinjaman tersebut. Hal ini akan memperbesar kemungkinan suatu perusahaan mengalami financial distress. Adanya pengaruh Debt to Equity Ratio (DER) yang signifikan terhadap Financial Distressserupa dengan hasil penelitian yang dilakukan oleh Dermawan Sjahrijal (2008) dan Hendra, et, al. (2017).

\section{SIMPULAN}

Hasil telaah laporan keuangan tahunan perusahaan pertambangan batu barayang terdaftar di Bursa Efek Indonesia Periode 2017-2018 diperoleh informasi bahwa terdapat lima perusahaan mengalami financial distress. Ukuran perusahaan dan Debt to Equity Ratio (DER)secarasignifikan berpengaruh terhadap peluang perusahaan pertambangan batu bara yang terdaftar di Bursa Efek Indonesia Periode 2017-2018 mengalami financial distress. Upaya yang dapat dilakukan agar perusahaan perusahaan pertambangan batu bara yang terdaftar di Bursa Efek Indonesia Periode 2017-2018 tidak mengalami financial distress yakni dengan meningkatkan aset perusahaan dan lebihmengandalkan pendanaan perusahaan dari ekuitas dibandingkan utang.

\section{DAFTAR PUSTAKA}

Afriyeni, Endang. (2012). Model Prediksi Financial Distress Perusahaan. Jurnal Polibisnis, 4.

Ainun, M. B. (2019). Pengaruh Kelompok Manajemen Puncak Terhadap Financial Distress: Studi Kasus Pada Perusahaan Perbankan Di Indonesia. Jurnal Akuntansi dan Bisnis: Jurnal Program studi Akuntansi, 5(2), 88-93.

Almilia, Luciana Spica. (2004). Analisis Faktor-Faktor yang Memengaruhi Kondisi Financial Distress Suatu Perusahaan yang Terdaftar di Bursa Efek Jakarta. Jurnal riset Akuntansi, 7(1).

Al-Khatib, Hazen B \& alaa Al-Horani. (2012). Predicting Financial Distress Of Public Companies Listed In Amman stock Exchange.European Scientific Journal, 8(15).

Amarilla, Ulfi, Nurcholisah, Kania, \& Diamonalisa Sofianty. (2017). Pengaruh Arus Kas Operasi dan Ukuran Perusahaan Terhadap Financial Distress. Jurnal Prosiding Akuntansi Universitas Islam Bandung, 3(2), 166-172.

Anggraini, Yunita. (2013). Analisis Financial Distress pada Sektor Pertambangan (Studi Kasus Pada Perusahaan yang Terdaftar di Bursa Efek Indonesia Periode 2011-2015) [Skripsi]. Jakarta: UIN Syarif Hidayatullah.

Ardimas, W., \& Wardoyo, W. (2015). Pengaruh Kinerja Keuangan Dan Corporate Social Responsibility Terhadap Nilai Perusahaan Pada Bank Go Public Yang Terdaftar Di BEI. Benefit: Jurnal Manajemen dan Bisnis, 18(1), 57-66.

Dwijayanti, S., \& Febrina, P. (2010). Penyebab, dampak, dan pbediksi dari financial distress serta solusi untuk mengatasi financial distress. Jurnal Akuntansi Kontemporer, 2(2), 191-205.

Ghozali, Imam. (2016). Aplikasi Analisis Multivariate dengan Program SPSS. Semarang: UNDIP.

Ginting, D. Y. (2018). Analisis Pengaruh Rasio Keuangan, Inflasi, Likuiditas serta Ukuran Perusahaan terhadap Financial Distress pada Perusahaan Manufaktur yang Terdaftar di Bursa Efek Indonesia pada Tahun 2013-2016 (Doctoral dissertation, STIE YKPN).

Harahap, Sofyan Syafri. (2006). Analisis Kritis Atas Laporan Keuangan. Jakarta: Rajawali Pers.

Hendra, Afrizal, \& Diah P.A, Enggar. (2018). Faktor-Faktor yang Memengaruhi Financial Distress (Studi Empiris Pada Perusahaan Pertambangan yang Terdaftar di Bursa Efek Indonesia Periode 20142016). Jambi: Universitas Jambi.

Indrasari, A., Yuliandhari, W. S., \& Triyanto, D. N. (2016). Pengaruh Komisaris Independen, Komite Audit, Dan Financial Distress Terhadap Integritas Laporan Keuangan. Jurnal Akuntansi, 20(1), 117-133.

Latan, Hengky. (2014). Aplikasi Analisis Data Statistik Untuk Ilmu Sosial Sains dengan IBM SPSS. Bandung: Alfabeta

Liana, D., \& Sutrisno. (2014).Analisis Rasio Keuangan untuk Memprediksi Kondisi Financial Distress Perusahaan Manufaktur, 1(2), 52-62.

Murni, Mayang. (2018). Analisis Faktor-Faktor yang Memengaruhi Tingkat Financial distress pada Perusahaan Manufaktur yang Terdaftar di BEI Tahun 2010-2014. Jurnal Akuntansi dan Bisnis, Vol 4 (1) Bulan Mei 2018. 
Nasution, Sri Hartati. (2016). Analisis Financial Distress pada Sektor Pertambangan (Studi Kasus Pada Perusahaan yang Terdaftar di Bursa Efek Indonesia Periode 2011-2015)[Skripsi]. Jakarta: UIN Syarif Hidayatullah.

Oktariani, N. W., \& Mimba, N. P. S. H. (2014). Pengaruh karakteristik perusahaan dan tanggung jawab lingkungan pada pengungkapan tanggung jawab sosial perusahaan. E-Jurnal Akuntansi, 402-418.

Puri, Ni Wayan Krisnayanti Arwinda dan Merkusiwati, Ni Kt Lely A. (2014). Pengaruh Mekanisme Corporate Governace, Likuiditas, Leverage, dan Ukuran Perusahaan pada Financial Distress. E-Jurnal Akuntansi Universitas Udayana, 7(1), hal. 93-106.

Riyanto, Bambang. (2008). Dasar-Dasar Pembelanjaan Perusahaan. Yogyakarta: GPFE.

Sjahrial, Dermawan. (2012). Pengantar Manajemen KeuanganEdisi 4. Jakarta: Mitra Wacana Media. 